\title{
PERSPEKTIF PENDIDIKAN ISLAM TENTANG REKONSTRUKSI REVOLUSI KULTURAL SUMBER DAYA MANUSIA
}

\author{
Muhammad Isnaini \\ Dosen Fakultas Tarbiyah, Ketua Badan Penelitian dan Pengembangan Pendidikan Islam (BP3i) \\ Fakultas Tarbiyah IAIN Raden Fatah Palembang \\ Email: isnain_m@yahoo.co.id
}

\begin{abstract}
Reconstruction or the strive of rebuilding and developing human resources should not only focused on the improvement of physical skill, but also non-physic sectors like values system, religious norms, and moral values. One of the causes of multidimensional crisis faced by Indonesian people is stemming from their own mistakes in which they give more emphasis on physical development than non-physic. It has to be considered a valuable lesson for society, especially for education organizers. Big physical capital does not guarantee that it can prevent, save, or brighten Indonesian people from crisis when non-physic side of human resources does not become the priority.
\end{abstract}

Key words: reconstruction, human resources, Islamic education, and cultural revolution

\begin{abstract}
Abstrak: rekonstruksi dan pengembangan sumber daya manusia tidak hanya ditujukan kepada pengembangan sektor fisik tetapi juga kepada sector non fisik system nilai, norma agama, nilai moral Salah satu penyebab dari krisis multidimensi yang dihadapi oleh masyarakat Indonesia adalah mengubah cara berpikir terhadap kesalahan yang lebih menekankan pada pembangunan fisik daripada non fisik. Ini sebagai bahan pertimbangan yang sangat bernilai bagi masyarakat, khusunya dalam menangani masalah pendidikan. Modal fisik yang besar tidak selamanya akan menjamin bahwa masyarakat Indonesia akan terbebas dari krisis apabila pengembangan sumber daya manusia secara non firik tidak diutamakan.
\end{abstract}

Kata Kunci: rekonstruksi, sumber daya manusia, revolusi budaya

\section{PENDAHULUAN}

Salah satu problem serius yang dihadapi oleh masyarakat atau negara ini adalah masalah sumber daya manusia. Problem ini bukan hanya menimpa dunia politik, budaya, dan agama, tetapi juga pendidikan. Karena kebermaknaan hidup seseorang ditentukan oleh kemampuannya dalam menjawab tantangan yang dihadapinya. Ia layak disebut sukses menjalani tugasnya sebagai khalifah di muka bumi, bilamana tantangan yang dihadapinya tidak mengorbankannya menjadi sosok manusia yang menyerah kalah dalam kegagalan." (Mahfud, 2006: 19). Banyak masalah di dunia pendidikan yang berhubungan dengan masalah kondisi sumber daya manusia. Ketika masyarakat di negara-negara maju memperbincangkan masalah peningkatan peradabannya, masyarakat atau negara ini masih sibuk mengurus upaya membenahi sektor sumber daya manusianya (Mahfud, 2006: 19).
Realitas dalam kehidupan kemasyarakatan dan kebangsaan ditentukan oleh salah satu potret berupa hubungan antara pendidikan dan sumber daya manusia. Ketika kondisi sumber daya manusia berkualitas unggul seperti mampu menunjukkan prestasi-prestasi besar, maka yang akan mendapatkan penilaian awal adalah peran dunia pendidikan Islam yang ikut menentukannya. Ada berbagai macam atau banyak sekali tantangan dan masalah yang sedang dihadapi oleh dunia pendidikan Islam di tanah air. Semakin hari tantangan pendidikan Islam semakin berat dan kompleks. Kompleksitas masalah dan tantangan tersebut setidaknya ada dua tantangan berikut (www. syirah.com/new/index.php?).

Pertama, tantangan yang hadir dari luar dan biasa disebut sebagai tantangan global. Tantangan ini tidak bisa dihindari begitu saja. Justru sebaliknya kita harus merebut peran dan bisa mengikuti perkembangan globalisasi. Karena dalam era globalisasi, perkembangan 
teknologi dan informasi sangat cepat dan canggih sekali. Dalam konteks semacam ini, maka pendidikan Islam harus ikut serta dan secara aktif merespons dengan menawarkan segala hal sesuai dengan tuntutan zaman.

Kedua, masalah dan tantangan otonomi pendidikan. Tantangan ini muncul seiring dengan diberlakukannya kebijakan otonomi daerah di Indonesia yang pada akhirnya berimplikasi pada pendidikan dengan lahirnya otonomi pendidikan. Pada satu sisi, tentu saja hal ini adalah sesuatu yang positif, tetapi di sisi lain kita harus menyadari bahwa di era ini persaingan semakin ketat antara satu lembaga pendidikan dengan lainnya. Maka, jelas diperlukan sumber daya manusia yang berkualitas dan sumber pendanaan yang kuat dan besar. Tantangan-tantangan di atas, tentu saja perlu segera direspon secara positip, manakala tidak segera direspons, lambat laun pendidikan Islam pasti ditinggal.

Dunia pendidikan mempunyai kompleksitas masalah, dari masalah dasar filosofis, gagasan, visi, misi, institusi, program, manajemen, sumber daya manusia bidang kependidikan, lingkungan, pendidikan, pembiayaan, kepercayaan, dan partisipasi masyarakat, kualitas out put pendidikan, serta relevansinya dengan dinamika masyarakat dan tuntutan sosio kultural sekitarnya.

\section{SDM DAN ASPEK-ASPEK YANG PERLU DIPAHAMI}

Memahami masalah pembangunan atau pengembangan sumber daya manusia perlu dikemukakan hal-hal mendasar yang perlu dipahami sebagai berikut:

Pertama: pengembangan sumber daya manusia pada hakikatnya adalah upaya untuk mewujudkan dan mengembangkan seluruh daya manusia secara terpadu, sehingga diperoleh kompetensi-kompetensi tertentu. Karena sifat peningkatan dalam kualitas ini, maka pengembangan sumber daya manusia menganut paradigma nilai tambah baik dalam konteks teknologi, ekonomi, maupun sumber daya manusia adalah suatu mentefak (yaitu perubahan pada tingkat pikiran, gagasan, teori, nilai dan paradigma). Dengan demikian nilai tambah tersebut memerlukan elaborasi pada tingkat spesifik yaitu budaya perubahan satu lingkungan yang lebih besar sebagai kepompong budaya manusia, atau perubahan ekosistem manusia, seperti pranata sosial dan sebagainya, dengan artefak (yaitu perubahan fisik yang terjadi sebagai hasil intervensi manusia terhadap lingkungannya dengan ilmu dan teknologi).

Kedua, sesuai dengan sejarah perkembangannya, yang awalnya berpijak pada nilai tambah. Nilai tambah sebagai paradigma pembangunan setidaknya mempunyai dimensi makna lain, yaitu makna non ekonomis pada dimensi kemanusiaan, nilai ekonomis menjadikan manusia lebih produktif, dan nilainya menjadi lebih unggul secara ekonomuis. Sedangkan nilai tambah insani (kemanusiaan) menjadikan manusia lebih tinggi harkat dan martabat kemanusiaannya, yaitu manusia yang lebih berbudaya, berakhlak, beriman dan bertaqwa, berseni dan sebagainya.

Ketiga, secara empiris, pengembangan sumber daya manusia meliputi empat aspek yang saling terkait yaitu: 1) Peningkatan kesejahteraan kualitas hidup, 2) Pengembangan tenaga dan kesempatan kerja, 3) Pengembangan potensi insani, (akal, qolbu, serta fisik), 4) Pengembangan kemampuan menguasai, memanfaatkan dan mengembangkan teknologi.

Keempat, pada tingkat makro perkembangan sumber daya manusia akan terjadi sebagai hasil interaksi antara pertumbuhan/perkembangan ekonomi, perkembangan sosial budaya (termasuk nilainilai spiritual) dan perkembangan serta penerapan teknologi. Ketiga proses tersebut dapat berpengaruh secara sinergis terhadap perkembangan sumber daya manusia. Berbeda dengan interdepedensi diatas perkembangan kualitas sumber daya manusia, suatu bangsa dapat makin mempercepat pertumbuhan ekonomi, namun sebaliknya, pertumbuhan ekonomi tidak dengan sendirinya menjamin terjadinya perkembangan kualitas sumber daya manusia. Perkembangan dan pertumbuhan ekonomi yang berorientasi pada "nilai tambah" yang memungkinkan pengaruhnya pada 
perkembangan kualitas sumber daya manusia (Hasan, 2000: 55-57).

\section{BAHAYA REVOLUSI BUDAYA}

Umat manusia sekarang menghadapi tragedi yang bernama revolusi kultural, yang potensial mengancam kehancuran masa depannya, dan diantara penyebab utamanya adalah kemajuan ilmu pengetahuan dan teknologi yang sangat pesat, khususnya teknologi informasi yang tanpa dibingkai oleh kekuatan moral dan agama. Revolusi kultural tidak lagi menjadi mimpi di siang hari, tetapi hadir dalam setiap gerak kehidupan manusia dan masyarakat.

Revolusi budaya telah menjadi semacam "anggur" yang gampang diminum oleh masyarakat selaku konsumen. Masyarakat menjadi ladang empuk yang digunakan oleh setiap produsen yang bermaksud mengambil keuntungan berlipat ganda dengan dalih demi Iptek dan kemajuan kultural. Sudah banyak kejadian di masyarakat mengenai tragedi sosial-kultural yang disebabkan kegagalan masyarakat dalam membaca dan mengadaptasikan dirinya dengan perubahan besar.

Kemajuan iptek tersebut lebih didayagunakan untuk tujuan-tujuan militer, dan kemajuan-kemajuan yang tidak bertanggungjawab, yang mengancam masa depan bumi dan seluruh macam kehidupannya, wajah bumi menjadi berubah gara-gara kemajuan IPTEK yang tidak terkendali, dan lingkungan hidup sangat menyedihkan akibat perbuatan manusia yang merusaknya, sekarang terasa pentingnya diadakan hubungan kerjasama antara akal dan iman menghadapi kekonyolan dan kegilaan bunuh diri yang akan menenggelamkan kemanusiaan (hal ini merupakan pernyataan Sekjen Institut Internasional yang beranggotakan 80 pakar berbagai ilmu, dan 20 orang diantara peraih Nobel) (Hasan, 2000: 65).

Lebih dari 30 ayat dalam Al-Qur'an yang menyampaikan keprihatinan terhadap terjadinya kerusakan lingkungan hidup di Bumi, baik lingkungan alam maupun lingkungan sosial, yang sumbernya tidak lain adalah perbuatan manusia itu sendiri, seperti dalam Al-Baqarah:
11, 30, dan 205 (Hasan, 2000: 68). Ayat ini menekankan soal sumber daya manusia yang dinilai gagal menjalankan fungsi moral ekologisnya, sehingga mereka (manusia) terjerumus dalam suatu perilaku-perilaku yang merugikan sesama manusia maupun alam semesta (lingkungan hidup). Hal ini pula yang perlu diingatkan kepada manusia bahwa kehadirannya di muka bumi ini membutuhkan kontribusi nilai-nilai edukasi (kependidikan) moral yang bisa membimbingnya ke jalan yang benar dan bertanggungjawab. Sudah banyak ditemukan manusia terdidik, namun dalam hidup kesehariannya tidak mencerminkan kalau dirinya sebagai manusia terdidik.

Pemikiran terhadap masalah pendidikan sumberdaya manusia tersebut sejalan dengan pemikiran pemikir muslim kenamaan AlGhazali. Al-Ghazali merupakan salah satu ulama yang serius memikirkan masalah-masalah pendidikan (Hasan, 2008). Al-Ghazali merupakan figur yang dapat dijadikan acuan keteladanan dalam dunia pendidikan, karena ia punya perhatian khusus terhadap masalah pengembangan sumber daya manusia yang berpangkal pada masalah pendidikan moral kerakyatan. Artinya, dalam menjalankan tugas kekhalifahan di muka bumi, manusia harus terdidik secara moral supaya peran yang dilakukan benar-benar sejalan dengan ajaran Ilahi, dan bukan mengikuti segala kemauan yang mengarah pada perusakan dan penghancuran.

Bagi masyarakat pembelajar, pemikiran kependidikan Al-Ghazali tersebut dapat dijadikan sebagai sumber referensi pemikiran untuk membangun dunia pendidikan Islam di Indonesia, khususnya pendidikan etikanya, yang mengandung substansi pencegahan diri dari kemungkinan melakukan tindakan yang merugikan orang lain dan makhluk Tuhan lainnya.

\section{REKONSTRUKSI BERDASARKAN KE- AZAZIAN PENDIDIKAN ISLAM}

Dalam pemikiran ahli fikih kenamaan Sahal Mahfud, pendidikan pada dasarnya adalah usaha sadar yang membentuk watak dan perilaku secara sistematis, terencana, dan terarah (Mahfudh, 1994: 257). Usaha seperti 
menunjukkan, bahwa dunia pendidikan merupakan tempatnya aktifitas yang mengerahkan berbagai kemampuan terbaik untuk menyukseskan cita-cita luhur berkaitan dengan pembentukan sumber daya manusia Indonesia.

Menurut Tholchah Hasan, pembaruan pemikiran Islam tidak sekedar bermakna menghidupkan kembali dan memurnikannya namun lebih dari itu harus unsur menggerakkan dan mendinaminasi. .Jelas di sini, bahwa wawasan pembaruan pemikiran Islam yang dibangunnya sangat luas, tidak terbatas pada pembaruan yang trivial, tetapi elementer, memasuki relung-relung kehidupan yang lebih luas, mencakup sosial, moral, dan budaya. Dinaminasi dalam konteks makro inilah yang hendak ditekankannya terkait pemberdayaan umat (sumber daya manusia) Islam. Karena umat Islam sudah semakin ketinggalan dengan non-muslim dalam berbagai aspeknya, terutama dibidang pemberdayaan sumber daya manusia, padahal secara normatif ajaran Islam secara lengkap meletakkan dasar-dasar ajarannya meliputi berbagai aspek kehidupan (sosial, politik, ekonomi, budaya dan sebagainya).

Pada tingkat idividual, pendidikan memberikan kreatifitas, kesadaran estetis serta bersosialisasi dengan norma-norma, nilai-nilai dan keyakinan sosial yang baik. Orang yang berpendidikan diharapkan lebih mampu menghargai atau menghormati perbedaan dan pluralitas budaya sehingga memiliki sikap yang lebih terbuka terhadap keanekaragaman budaya. Sedangkan fungsi kependidikan merujuk pada sumbangan kependidikan terhadap perkembangan dan pemeliharaan pendidikan diharapkan bagi manusia memiliki kesadaran untuk belajar sepanjang hayat, selalu merasa ketinggalan informasi, ilmu pengetahuan serta teknologi sehingga terus terdorong untuk maju dan terus belajar (Hasan, 2008: 4-5 ).

Pendidikan memang harus menjadi investasi sumber daya manusia yang memberi manfaat material maupun non materi. Manfaat non materi dari pendidikan adalah diperolehnya kondisi kerja yang lebih baik, kepuasan kerja, efisiensi, konsumsi, kepuasan menikmati masa pensiun dan manfaat hidup yang lebih lama karena peningkatan gizi dan kesehatan. Manfaat materi adalah manfaat ekonomis yaitu berupa kecukupan pendapatan seseorang yang telah menyelesaikan tingkat pendidikan tertentu dibandingkan dengan pendapatan lulusan pendidikan dibawahnya. Sumber daya manusia yang berpendidikan akan menjadi modal utama pembangunan nasional, terutama untuk perkembangan ekonomi. Semakin tinggi tingkat pendidikan masyarakatnya maka semakin mudah bagi negara untuk membangun bangsanya.

Dalam pasal 3 UU Nomor 20 Tahun 2003 (Sistem Pendidikan Nasional), disebutkan, bahwa pendidikan nasional berfungsi mengembangkan kemampuan dan membentuk watak serta peradaban bangsa yang bermartabat dalam rangka mencerdaskan kehidupan bangsa, bertujuan untuk berkembangnya potensi peserta didik agar menjadi manusia yang beriman dan bertakwa kepada Tuhan Yang Maha Esa, berakhlak mulia, sehat, berilmu, cakap, kreatif, mandiri, dan menjadi warga negara yang demokratis serta bertanggung jawab.

Tujuan yang terumus dalam pelajaran agama atau secara yuridis tersebut hanya menjadi contoh, bahwa perumus kebijakan suatu pendidikan agama seringkali menghadapi masalah sulit ketika masalah pembentukan kepribadian manusia dihubungkan dengan realitas sosial di sekitarnya, serta masa depan perjalanan hidupnya. Hal ini menjadi lebih sulit lagi dalam perumusannya, ketika dikaitkan dengan esensi manusia yang sedang duduk di bangku kuliah (mahasiswa). Meski demikian, rumusan yang tujuan singkat atau panjang berkaitan dengan pembentukan diri manusia, tidak akan pernah mengurangi cita-cita pendidikan yang menempatkan manusia sebagai subjek atau fokus perhatiannya.

Pendidikan dalam istilah al-Qur'an-nya disebut "tarbiyah", yang mengandung arti "penumbuhan" atau "peningkatan jasmani anak".pertama-tama ialah penumbuhan dan peningkatan segi jasmani anak, dengan terutama si ibu tanpa pamrih dan atas rasa cinta kasih sayang yang semurni-murninya mencurahkan diri dan perhatiannya kepada pertumbuhan anaknya. Hubungan emosional yang amat peka 
dan penuh kemesraan si ibu menjadi taruhan "survival"si anak memasuki dunia kehidupan. Bahkan hubungan itu sudah terbentuk saat berada dalam kandungan.sedemikian pekanya unsur cinta kasih itu, sehingga tempat janin dalam bahasa arab disebut rahm (rahim secara etimologis berarti kasih sayang) (Majid, 1997: 114).

Menilai dan mendiskusikan (membahas) masalah manusia seperti tidak kenal habis. Ketika dirinya dibahas tentang peran kekhalifahannya di muka bumi, muncul pembelaan dan bahkan mempertenyakan banyak hal, yang semakin membuat lingkaran semakin besar. Secara filosofis, Al-Ghazali memandang manusia berarti berpikir secara loyalitas tentang diri manusia itu sendiri mengenai struktur eksistensinya, hakikat atau esensinya, pengetahuan dan perbuatannya, tujuan hidupnya dan dan segi-segi lain yang mendukung sehingga tampak jelas wujud manusia yang sebenarnya.

Al-Ghazali menggunakan empat istilah dalam membahas tentang esensi manusia yaitu: 1) hati (qalb) ialah, yang halus, ketuhanan yang bersifat kerohanian, ia dengan hati yang bertubuh ada hubungannya, 2) ruh adalah yang halus, yang mengetahui, dan yang merasa dari manusia, 3) jiwa (nafs) yaitu yang halus yang telah kami sebutkan yakni hakekat manusia; diri dan zatnya, 4) akal (aql) kadang ditujukan dan dimaksudkan yang memperoleh pengetahuan, dan itu adalah hati yakni yang halus, kadang dimaksudkan sifat orang yang berilmu, dan kadang ditunjukan dan dimaksudkan tempat pengetahuan yakni yang mengetahui.

Penggunaan keempat istilah diatas menunjukkan bahwa kajian Al-Ghazali terhadap esensi manusia sangat mendalam menyertai sepanjang perkembangan pemikirannya. Saat berbicara tentang filsafat, ia lebih sering menggunakan kata nafs dan akal, sedangkan ruh dan qalb lebih banyak dijumpai dalam kitabkitabnya ditulis setelah menekuni tasawuf, akan tetapi hal itu tidak mengubah pandangannya tentang esensi manusia (Ibnu Rusd, 1998: 3031).

\section{RELASI KEPENTINGAN PUBLIK}

Pendidikan bukan sekedar kegiatan alih pengetahuan dan keahlian akan tetapi juga kegiatan alih nilai dan budaya dalam suatu proses yang cukup berkembang. Suatu strategi atau konsep pendidikan bagi suatu umat atau bangsa tidak mungkin dapat disusun dengan baik, apabila tidak didasarkan pada: pertama: latar belakang agama dan budaya umat atau bangsa yang bersangkutan, kedua, cita-cita umat atau bangsa, ketiga: tantangan yang dihadapi oleh umat atau bangsa tersebut (Hasan, 2000: 215-216). Kedua aspek ini menentukan konstruksi ideal pendidikan di masa depan, karena latar belakang agama dan hudaya, serta cita-cita umat atau realitas kepentingan publik (kemaslahatan masyarakatan) merupakan suatu integrasi yang menjadi inti atau kekuatan pendidikan (Setianingsih, 2008: 2).

Salah satu cita-cita yang bermaksud didekonstruksi masyarakat muslim, adalah masalah ketertinggalannya yang berelasi dengan masalah kebodohan. Hal seperti inilah yang disinggung oleh Syakib Arsalan yang menyebut, bahwa yang menjadi sebab-sebab terpenting kemunduran umat Islam antara lain: 1) karena kebodohan, yang menjadikan mereka tidak mampu membedakan antara tuak dan cuka (tidak mampu membedakan antar manfaat dan madlarat), mudah dibohongi dan gampang ditipu, 2) karena kebobrokan moral, sehingga tidak mampu mengendalikan hawa nafsunya dan tidak sanggup mengontrol sikap dan perilakunya sebagai seorang yang seharusnya hidup terhormat dan menjadi teladan. Lebih parah lagi apabila kebobrokan moral sudah merasuki kaum elit mereka, 3) karena kehilangan karakter, menjadi orang-orang yang tidak mempunyai harga diri dan tidak memiliki keberanian, kehilangan sifat dan sikap patriotisme, tidak sanggup menyampaikan kebenaran di hadapan penguasa (Hasan, 2007: 28).

Titik tekan dari uraian tersebut tertuju pada masalah pendidikan Islam sebagai pembebasan kebodohan dan "pembodohan diri" secara moralitas, karena dari kebodohan dan "pembodohann diri" inilah kemudian masyarakat atau publik muslim tertinggal, atau sumberdaya manusia gagal mencapai kemajuan- 
nya di bidang sains dan sektor strategis lainnya dalam kehidupan ini. Padahal, seperti dikatakan Tholchah Hasan, kemajuan sains dan teknologi yang terjadi begitu cepat, juga melahirkan suatu masyarakat yang baru, yang kerap disebut masyarakat ilmu pengetahuan atau knowledge society. Teknologi komunitas telah membantu penyebaran ilmu pengetahuan, dan selanjutnya pengembangan dan pemanfaatannya untuk meningkatkan kualitas kehidupan manusia. Selanjutnya kemajuan teknologi komunikasi telah membantu umat manusia untuk mengenal ilmu pengetahuan dengan lebih mudah, lebih cepat, lebih luas, lebih up to date. Manusia atau masyarakat dapat melihat berbagai peristiwa dan berita secara langsung dengan kemajuan teknologi informasi dan komunikasi, dengan antena parabola, dengan internet dan lain-lain, sehingga semua model kehidupan di dunia dapat diikuti dan disaksikan cukup di dalam kamar tidur tanpa dapat disensor oleh siapapun. Dalam era globalisasi yang didukung oleh kemajuan sains dan kecanggihan teknologi, akan membawa pertemuan dan pengenalan nilai-nilai budaya dan skala dunia, dan akan terjadi proses saling mempengaruhi diantara nilai-nilai tersebut, termasuk nilai-nilai agama dan moral. Seringkali nilai-nilai yang berasal dari budaya yang sedang menang (budaya barat) berada pada posisi yang selalu menang dan unggul, karena didukung oleh fasilitas, sarana teknis dan dana yang lebih kuat (Hasan, 2007: 12-13).

Di ruang yang lain, rontoknya beberapa ideologi-ideologi besar dunia juga membawa kelahiran nila-nilai kemanusiaan dan hakikat serta martabat manusia sebagai sesuatu yang harus dihormati. Hak-hak manusia dimanapun di dunia adalah sama, harus dihormati, dilindungi, dan dibela tanpa mengenal diskriminasi. Sejalan dengan itu pula setiap manusia wajib mempunyai rasa tanggungjawab memelihara masysrakat yang bebas dari ketakutan, bebas dari paksaan, dan bebas untuk mewujudkan hakikat dan martabat hidupnya sendiri dengan memperhatikan kepentingan bersama.

Masyarakat (sumber daya manusia) seperti itu merupakan profil atau gambaran masyarakat yang terbebas dari kebodohan.
Selama masyarakat masih tetap dalam lingkaran kebodohan, maka sulit diharapkan masyarakat ini akan bisa berkompetisi dengan bangsabangsa besar di muka bumi (Mahfudh, 2006: 7). Kata Ahmad Syafii Maarif, (1995: 11) manusia yang baik merupakan sosok manusia yang tidak menghabiskan masa hidup yang ringkas ini dengan sia-sia. Noeng Muhadjir menyebutkan, bahwa aktivitas pendidikan adalah aktivitas interaktif antara pendidik dan subjek didik untuk mencapai tujuan yang baik dengan cara yang baik dan dalam konteks positif (Thoha, 1996: 99).

Kemampuan mengendalikan diri memang penting dalam kehidupan ini, di samping mengembangkan diri.Hal ini telah diketahui sejak dulu sekali. Pada dekade 90-an (sekitar tahun 1995) muncul buku Goleman yang menjelaskan betapa pentingnya kemampuan mengendalikan diri tersebut. Ia menyebutnya emotional intelligence (EI) yang sering disingkat EQ (emotional quotient) yang oleh orang Indonesia dikenal kecerdasan emosi (Tafsir, 2006). Selain pendapat ini, tidak sedikit yang menyebut bahwa kemampuan mengendalikan diri juga dibutuhkan atau harus diimbangi dengan kecerdasan intelektual, kecerdasan moral, dan kecerdasan keagamaan (Mahfuzh, 2006: 12).

\section{SIMPULAN}

Potret pendidikan Islam di Indonesia menghadapi berbagai bentuk ujian yang tidak ringan. Salah satu ujiannya adalah revolusi kultural yang menyerang kehidupan anak-anak (masyarakat didik). Tidak sedikit ditemukan anak-anak yang terjerumus menjadi korban revolusi kultural. Kondisi demikian memerlukan rekonstruksi atau upaya membangun kembali kebijakan atau implementasi pendidikan Islam.

Perlu dipahami bersama, bahwa mengembangkan sumber daya manusia tidak semata terfokus pada peningkatan sektor ketrampilan (fisik), tetapi juga non-fisik seperti tata nilai, norma-norma keagamaan dan nilainilai moralitas. Salah satu penyebab krisis multidimensi yang dihadapi Indonesia yang bersumber dari kesalahan manusia Indonesia yang lebih mengutamakan pengembangan fisik 
dibandingkan pengembangan sisi non-fisik harus dapat dijadikan pelajaran berharga bagi masyarakat, khususnya pengelola pendidikan, bahwa modal fisik yang besar tidak menjadi jaminan mampu mencegah dan menyelamatkan dan mencerahkan Indonesia, khususnya mencerahkan sumber daya manusianya.

\section{DAFTAR RUJUKAN}

Abidin Ibnu Rusn, 1998, Pemikiran Pendidikan, Pustaka Pelajar Offset, Yogyakarta.

Ahmad Syafii Maarif, 1995, Membumikan Islam, Pustaka Pelajar, Yogyakarta.

Ahmad Tafsir, 2006, Filsafat Pendidikan Islam, Remaja Rosdakarya, Bandung.

Chabib Thoha,1996, Kapita Selekta Pendidikan Islam, Pustaka Pelajar, Yogyakarta. http://www.syirah.com/new/index.php?option=c om_content\&task=view\&id=180\&Itemid $=68$

Mahfud, 2006, Pribadi yang Pintar dan Benar, Materi Kultum bagi Kaum Terdidik, Prima Mustika, Surabaya.

Muhammad Tholhah Hasan, 2000, Diskursus Islam Kontemporer, Listafariska Putra,Jakarta.

Muhammad Tholhah Hasan, 2000. Perkembangan Global", Materi disampaikan dalam kuliah umum tanggal 16 Pebruari 2008.

Nur Cholish Madjid, 1997, Masyarakat Religius, Amanah Putra Nusantara, Jakarta.

Sahal Mahfudh, 1994. Nuansa Fiqih Sosial, LKIS Yogyakarta, Yogyakarta.

Undang-undang Nomor 20 Tahun 2003 tentang Sistem Pendidikan Nasional 